Article

\title{
Three New Myrsinol Diterpenes from Euphorbia prolifera and Their Neuroprotective Activities
}

\section{Jing Xu ${ }^{1}$, Daqing Jin ${ }^{2}$, Ping Guo ${ }^{3}$, Chunfeng Xie ${ }^{1}$, Lingzhi Fang ${ }^{1}$ and Yuanqiang Guo ${ }^{1,4, *}$}

1 State Key Laboratory of Medicinal Chemical Biology and Tianjin Key Laboratory of

Molecular Drug Research, College of Pharmacy, Nankai University, Tianjin 300071, China

School of Medicine, Nankai University, Tianjin 300071, China

3 Department of Analytical Chemistry, College of Pharmacy, Shenyang Pharmaceutical University, Shenyang 110016, China

4 State Key Laboratory of Bioactive Substance and Function of Natural Medicines, Institute of Materia Medica, Chinese Academy of Medical Sciences and Peking Union Medical College, Beijing 100050, China

* Author to whom correspondence should be addressed; E-Mail: victgyq@163.com;

Tel./Fax: +86-22-2350-2595.

Received: 9 July 2012; in revised form: 25 July 2012 / Accepted: 26 July 2012 /

Published: 9 August 2012

\begin{abstract}
Three new myrsinol diterpenes were isolated from the roots of Euphorbia prolifera. Their structures were elucidated as $2 \alpha-O$-isobutyryl-3 $\beta, 5 \alpha, 7 \beta, 10,15 \beta$ penta- $O$-acetyl-14 $\alpha$ - $O$-benzoyl-10,18-dihydromyrsinol (1), $2 \alpha$ - $O$-isobutyryl-3 $\beta$ - $O$-propionyl-5 $\alpha, 7 \beta, 10,15 \beta$-tetra- $O$-acetyl-10,18-dihydromyrsinol (2), and $2 \alpha, 14 \alpha$-di- $O$-benzoyl$3 \beta, 5 \alpha, 7 \beta, 10,15 \beta$-penta- $O$-acetyl-10,18-dihydromyrsinol (3) on the basis of spectroscopic data analyses (IR, ESI-MS, HR-ESI-MS, and 1D and 2D NMR). Their neuroprotective activities were evaluated and compounds $\mathbf{1}$ and $\mathbf{2}$ showed neuroprotective effects against $\mathrm{MPP}^{+}$-induced neuronal cell death in SH-SY5Y cells.
\end{abstract}

Keywords: Euphorbia prolifera; diterpenoids; myrsinol diterpenes; neuroprotective activities

\section{Introduction}

Euphorbia prolifera Buch-Ham, belonging to the family Euphorbiaceae, is a perennial herbaceous plant distributed in southwest China [1]. Its roots have been used as a folk medicine to treat 
inflammations and tumors [2]. Previous phytochemical investigations on E. prolifera revealed that the main and characteristic constituents are myrsinol-type diterpenes [3-9], which are rare in natural products and whose studies of biological activities are limited [6]. In the course of our survey on new and pharmacologically active substances in medicinal plants $[10,11]$, considerable attention has been given to the occurrence of compounds with neuroprotective effects, since these substances are expected to be useful for the treatment of nervous system diseases, such as Parkinson's disease [12]. As a continuation of the search for bioactive natural products, our further chemical investigation on the roots of E. prolifera led to the isolation of three new myrsinol diterpenes 1-3 (Figure 1). Their structures were elucidated as $2 \alpha-O$-isobutyryl- $3 \beta, 5 \alpha, 7 \beta, 10,15 \beta$-penta- $O$-acetyl-14 $\alpha$ - $O$-benzoyl-10,18dihydromyrsinol (1), $2 \alpha$ - $O$-isobutyryl-3 $\beta$ - $O$-propionyl-5 $\alpha, 7 \beta, 10,15 \beta$-tetra- $O$-acetyl-10,18-dihydromyrsinol (2), and $2 \alpha, 14 \alpha$-di- $O$-benzoyl-3 $\beta, 5 \alpha, 7 \beta, 10,15 \beta$-penta- $O$-acetyl-10,18-dihydromyrsinol (3) on the basis of spectroscopic data analyses (IR, ESI-MS, HR-ESI-MS, and 1D and 2D NMR). The neuroprotective activities against 1-methyl-4-phenyl-1,2,3,6-tetrahydropyridine ( $\left.\mathrm{MPP}^{+}\right)$-induced neuronal cell death in SH-SY5Y cells were also evaluated. Herein, we describe the isolation and structural elucidation of the three new natural myrsinol diterpenes and their neuroprotective activities.

Figure 1. Structures of compounds 1-3 from E. prolifera.

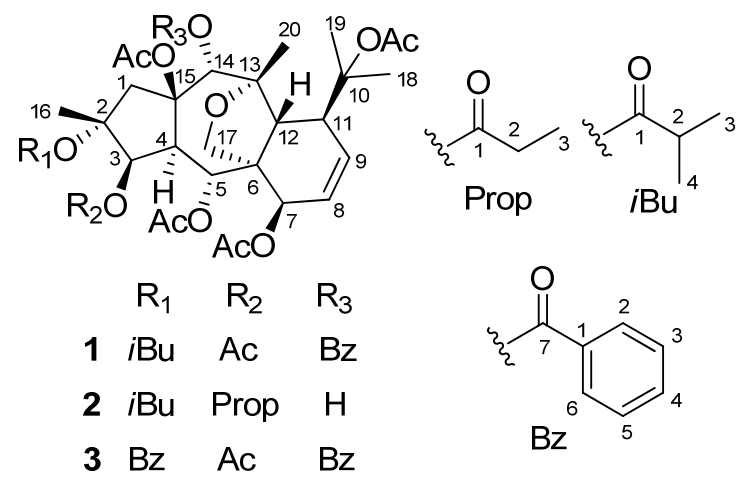

\section{Results and Discussion}

Compound 1 was isolated as colorless needles. Its molecular formula was determined as $\mathrm{C}_{41} \mathrm{H}_{52} \mathrm{O}_{15}$ on the basis of HR-ESI-MS $(\mathrm{m} / z \text { 807.3195 [M }+\mathrm{Na}]^{+}$, calcd. for $\mathrm{C}_{41} \mathrm{H}_{52} \mathrm{O}_{15} \mathrm{Na}$ 807.3204). The ${ }^{1} \mathrm{H}-\mathrm{NMR}$ spectrum of 1 exhibited two olefinic protons $\left[\delta_{\mathrm{H}} 6.17(1 \mathrm{H}, \mathrm{dd}, J=10.2,6.5 \mathrm{~Hz}, \mathrm{H}-8)\right.$, and $5.90(1 \mathrm{H}, \mathrm{dd}, J=10.2,5.6 \mathrm{~Hz}, \mathrm{H}-9)]$, four oxygenated methines $\left[\delta_{\mathrm{H}} 5.48(1 \mathrm{H}, \mathrm{d}, J=3.9 \mathrm{~Hz}, \mathrm{H}-3), 5.92\right.$ $(1 \mathrm{H}, \mathrm{d}, J=11.0 \mathrm{~Hz}, \mathrm{H}-5), 4.84(1 \mathrm{H}, \mathrm{d}, J=6.5 \mathrm{~Hz}, \mathrm{H}-7)$, and $5.78(1 \mathrm{H}, \mathrm{s}, \mathrm{H}-14)]$, and one oxygenated methylene $\left[\delta_{\mathrm{H}} 4.09\right.$ and 3.49 (each $1 \mathrm{H}, \mathrm{d}, J=8.8 \mathrm{~Hz}, \mathrm{H}_{2}-17$ )]. In addition, 11 methyls and one monosubstituted benzene ring were also revealed in the ${ }^{1} \mathrm{H}-\mathrm{NMR}$ spectrum. The ${ }^{13} \mathrm{C}$-NMR spectrum of 1 exihibited 41 carbon resonances. From the ${ }^{1} \mathrm{H}$ - and ${ }^{13} \mathrm{C}-\mathrm{NMR}$ spectra of $\mathbf{1}$, five acetyl groups $\left[\delta_{\mathrm{H}}\right.$ $2.13 \mathrm{~s}, 2.09 \mathrm{~s}, 2.05 \mathrm{~s}, 1.98 \mathrm{~s}$, and $1.96 \mathrm{~s} ; \delta_{\mathrm{C}} 170.6,170.3,170.2,169.2$, and $168.4(\mathrm{CO})$, and 22.4, 22.2, 21.0, 20.9, and $\left.20.8\left(\mathrm{CH}_{3}\right)\right]$, and one benzoyl group $\left(\delta_{\mathrm{H}} 8.09 \times 2 \mathrm{~d}, 7.42 \times 2 \mathrm{t}\right.$, and $7.56 \mathrm{t}$; $\delta_{\mathrm{C}} 129.6$, $129.9 \times 2,128.3 \times 2,133.2$, and 165.6) (Tables 1 and 2) were confirmative, and one isobutyryl group $\left(\delta_{\mathrm{H}} 2.24 \mathrm{q}, 0.83 \mathrm{~d}\right.$, and $1.08 \mathrm{~d} ; \delta_{\mathrm{C}} 18.2,18.8,34.3$, and 175.3) (Tables 1 and 2) was also deduced based on those reported diterpenes with isobutyryl groups from the genus Euphorbia [4,5,7]. Apart from the above 21 signals for the substituents (five acetoxy groups, one isobutyryloxy group, and one 
benzoyloxy group), there are additional 20 resonances exhibited for the parent skeleton in the ${ }^{13} \mathrm{C}-\mathrm{NMR}$ spectrum, which comprised four methyls (C-16, C-18, C-19, and C-20), two methylenes (C-1 and C-17), nine methines (C-3, C-4, C-5, C-7, C-8, C-9, C-11, C-12, and C-14), and five quaternary carbons (C-2, C-6, C-10, C-13, and C-15). By comparing the chemical shifts of C-1-C-20 of compound 1 with those of myrsinol diterpenes reported in the literature [4,5,7], the presence of the 10,18-dihydromyrsinol skeleton was obvious. In order to confirm the 10,18-dihydromyrsinol skeleton and determine the positions of the acyloxy groups, the following HMQC and HMBC experiments were performed. By the interpretation of $1 \mathrm{D}$ and 2D NMR spectra, the 10,18-dihydromyrsinol skeleton was defined (Figure 1). The HMBC correlations of the carbonyl signal at $\delta_{\mathrm{C}} 170.3$ with the proton signal at $\delta_{\mathrm{H}} 5.48(\mathrm{H}-3)$ indicated the presence of the one acetoxy group at C-3. Similarly, the long-range couplings of the carbonyl carbon signals at $\delta_{\mathrm{C}} 169.2,170.2$, and 165.6 with the proton signals at $\delta_{\mathrm{H}}$ $5.92(\mathrm{H}-5), 4.84(\mathrm{H}-7)$, and $5.78(\mathrm{H}-14)$ demonstrated the presence of the two acetoxy groups and one benzoyloxy group at C-5, C-7, and C-14, respectively. The positions of these remaining acyloxy groups were further elucidated by a NOESY experiment. The NOESY correlations of $\mathrm{H}-14\left(\delta_{\mathrm{H}} 5.78\right)$ and $\mathrm{H}-1 \beta\left(\delta_{\mathrm{H}} 2.44\right)$ to the methyl protons $\left(\delta_{\mathrm{H}} 2.09\right)$ of the $\mathrm{C}-15$ acetoxy group, and $\mathrm{H}_{3}-19\left(\delta_{\mathrm{H}} 1.53\right)$ to the methyl protons $\left(\delta_{\mathrm{H}} 2.13\right)$ of the $\mathrm{C}-10$ acetoxy group, implied that the two acetoxy groups were located at $\mathrm{C}-15$ and $\mathrm{C}-10$, respectively. Consequently, the isobutyryloxy group could be assigned only to $\mathrm{C}-2$ based on the chemical shift for C-2. By further analyzing the HMQC, HMBC, and ${ }^{1} \mathrm{H}-{ }^{1} \mathrm{H}$ COSY spectra (Figure 2), all the proton and carbon signals were assigned unambiguously. Thus, the planar structure of 1 was established.

Table 1. ${ }^{1} \mathrm{H}-\mathrm{NMR}$ spectroscopic data for compounds $\mathbf{1}-\mathbf{3}\left(\delta \mathrm{ppm}\right.$ in $\mathrm{CDCl}_{3}$ and $J$ in $\left.\mathrm{Hz}\right)$.

\begin{tabular}{|c|c|c|c|}
\hline Position & 1 & 2 & 3 \\
\hline $1 \alpha$ & $3.14 \mathrm{~d}(17.2)$ & $3.85 \mathrm{~d}(16.8)$ & $3.57 \mathrm{~d}(17.6)$ \\
\hline$\beta$ & $2.44 \mathrm{~d}(17.2)$ & $2.13 \mathrm{~d}(16.8)$ & $2.51 \mathrm{~d}(17.6)$ \\
\hline 3 & $5.48 \mathrm{~d}(3.9)$ & 5.22 br s & $5.47 \mathrm{~d}(3.7)$ \\
\hline 4 & $3.68 \mathrm{dd}(11.0,3.9)$ & $3.00 \mathrm{~d}(11.0)$ & $3.92 \mathrm{~d}(11.0,3.70)$ \\
\hline 5 & $5.92 \mathrm{~d}(11.0)$ & $5.83 \mathrm{~d}(11.0)$ & $6.02 \mathrm{~d}(11.0)$ \\
\hline 7 & $4.84 \mathrm{~d}(6.5)$ & $4.79 \mathrm{~d}(7.0)$ & $4.89 \mathrm{~d}(6.6)$ \\
\hline 8 & $6.17 \mathrm{dd}(10.2,6.5)$ & $6.12 \mathrm{dd}(9.8,7.0)$ & $6.18 \mathrm{dd}(10.0,6.6)$ \\
\hline 9 & $5.90 \mathrm{dd}(10.2,5.6)$ & $5.90 \mathrm{dd}(9.8,5.6)$ & $5.90 \mathrm{dd}(10.0,5.6)$ \\
\hline 11 & $3.17 \mathrm{dd}(5.6,3.0)$ & $3.13 \mathrm{~d}(5.6)$ & $3.16 \mathrm{~d}(5.6)$ \\
\hline 12 & $3.13 \mathrm{~d}(3.0)$ & $3.10 \mathrm{~s}$ & $3.20 \mathrm{~s}$ \\
\hline 14 & $5.78 \mathrm{~s}$ & $4.05 \mathrm{~d}(9.0)$ & $5.81 \mathrm{~s}$ \\
\hline 16 & $1.31 \mathrm{~s}$ & $1.38 \mathrm{~s}$ & $1.46 \mathrm{~s}$ \\
\hline \multirow[t]{2}{*}{17} & $4.09 \mathrm{~d}(8.8)$ & $3.99 \mathrm{~d}(8.7)$ & $4.18 \mathrm{~d}(8.8)$ \\
\hline & $3.49 \mathrm{~d}(8.8)$ & $3.47 \mathrm{~d}(8.7)$ & $3.53 \mathrm{~d}(8.8)$ \\
\hline 18 & $1.62 \mathrm{~s}$ & $1.58 \mathrm{~s}$ & $1.55 \mathrm{~s}$ \\
\hline 19 & $1.53 \mathrm{~s}$ & $1.48 \mathrm{~s}$ & $1.62 \mathrm{~s}$ \\
\hline 20 & $1.20 \mathrm{~s}$ & $1.38 \mathrm{~s}$ & $1.15 \mathrm{~s}$ \\
\hline \multirow[t]{3}{*}{ 2-OR } & $2.24 \mathrm{q}(7.0)$ & $2.41 \mathrm{q}(7.1)$ & $7.62 \mathrm{~d}(7.3)$ \\
\hline & $0.83 \mathrm{~d}(7.0)$ & $1.08 \mathrm{~d}(7.1)$ & $6.95 \mathrm{t}(7.3)$ \\
\hline & $1.08 \mathrm{~d}(7.0)$ & $1.10 \mathrm{~d}(7.1)$ & $7.31 \mathrm{t}(7.3)$ \\
\hline
\end{tabular}


Table 1. Cont.

\begin{tabular}{ccccc}
\hline \multicolumn{2}{c}{ Position } & $\mathbf{1}$ & $\mathbf{2}$ & $\mathbf{3}$ \\
\hline $3-$ OR & 2 & $2.05 \mathrm{~s}$ & $2.33 \mathrm{q}(8.1)$ & $2.09 \mathrm{~s}$ \\
& 3 & & $1.11 \mathrm{t}(8.1)$ & \\
5 -OAc & 2 & $1.98 \mathrm{~s}$ & $1.93 \mathrm{~s}$ & $2.04 \mathrm{~s}$ \\
$7-$ OAc & 2 & $1.96 \mathrm{~s}$ & $1.91 \mathrm{~s}$ & $1.99 \mathrm{~s}$ \\
$10-$ OAc & 2 & $2.13 \mathrm{~s}$ & $2.04 \mathrm{~s}$ & $2.17 \mathrm{~s}$ \\
$14-$ OR & $2 / 6$ & $8.09 \mathrm{~d}(7.2)$ & $2.85 \mathrm{~d}(9.0)(14-\mathrm{OH})$ & $7.72 \mathrm{~d}(7.4)$ \\
& $3 / 5$ & $7.42 \mathrm{t}(7.2)$ & & $7.33 \mathrm{t}(7.4)$ \\
& 4 & $7.56 \mathrm{t}(7.2)$ & & $7.52 \mathrm{t}(7.4)$ \\
$15-O A c$ & 2 & $2.09 \mathrm{~s}$ & $1.91 \mathrm{~s}$ & $2.09 \mathrm{~s}$ \\
\hline
\end{tabular}

Figure 2. Selected HMBC, ${ }^{1} \mathrm{H}^{-1} \mathrm{H}$ COSY, and NOESY correlations of compound $\mathbf{1}$.

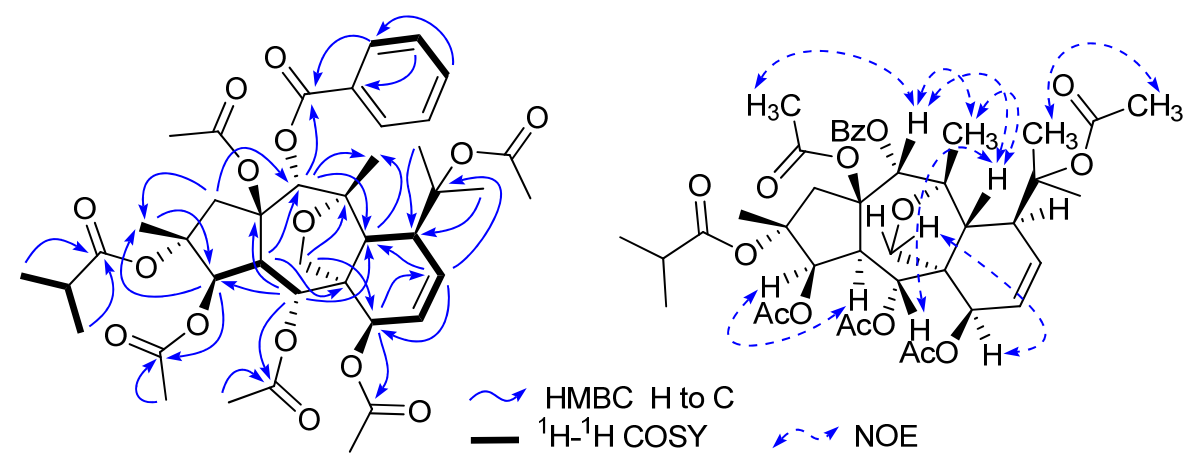

The relative configuration of $\mathbf{1}$ was elucidated based on the NOESY spectrum and the comparison of NMR data with those of reported myrsinol diterpenes in the literature $[4,5,7,13,14]$. For all of the reported natural myrsinol diterpenes, the three rings (5/7/6) comprising the myrsinol-skeleton are trans-fused with each other, $\mathrm{H}_{3}-16, \mathrm{H}-12$, the side chain at $\mathrm{C}-11$, and the acyloxy group at $\mathrm{C}-15$ are biogenetically $\beta$-oriented, and $\mathrm{H}-4$ and $\mathrm{H}_{2}-17$ are biogenetically $\alpha$-oriented [7,13]. NOESY correlations observed for $\mathrm{H}-3 / \mathrm{H}-4, \mathrm{H}-5 / \mathrm{H}-12, \mathrm{H}-12 / \mathrm{H}-14, \mathrm{H}-7 / \mathrm{H}_{2}-17$, and $\mathrm{H}-12 / \mathrm{H}_{3}-20$, suggested that $\mathrm{H}-3, \mathrm{H}-4$, and $\mathrm{H}-7$ were in $\alpha$-positions, and $\mathrm{H}-5, \mathrm{H}-12, \mathrm{H}-14$, and $\mathrm{H}_{3}-20$ were in $\beta$-positions. These assignments were consistent with the configuration of reported 10,18-dihydromyrsinol diterpenes $[7,13]$. Therefore, the structure of compound 1 was characterized as $2 \alpha-O$-isobutyryl-3 $\beta, 5 \alpha, 7 \beta, 10,15 \beta$-penta$O$-acetyl-14 $\alpha$ - $O$-benzoyl-10,18-dihydromyrsinol.

Compound 2 possessed a molecular formula of $\mathrm{C}_{35} \mathrm{H}_{50} \mathrm{O}_{14}$ based on the HR-ESI-MS $(\mathrm{m} / z$ 717.3101 $[\mathrm{M}+\mathrm{Na}]^{+}$, calcd. for $\mathrm{C}_{35} \mathrm{H}_{50} \mathrm{O}_{14} \mathrm{Na}$ 717.3098). The ${ }^{1} \mathrm{H}$ - and ${ }^{13} \mathrm{C}-\mathrm{NMR}$ spectra of 2 were very similar to those of compound 1, which implied that compound 2 should also be a 10,18-dihydromyrsinol diterpene. Close similarities of the chemical shifts from C-1 to C-20 in $\mathbf{2}$ with those in $\mathbf{1}$ (Table 2) suggested that compounds $\mathbf{2}$ and $\mathbf{1}$ had the same parent skeleton [4,5,7]. In addition to the 20 skeletal carbons, the ${ }^{13} \mathrm{C}-\mathrm{NMR}$ spectrum revealed additional 15 carbons for the substituent groups, which were deduced and defined as four acetoxy groups, one isobutyryloxy group, and one propinoyloxy group based on the analyses of HMQC and HMBC spectroscopic data of 2 [4,5,7]. The locations of the six acyloxy groups were elucidated by the interpretation of the HMBC spectrum as in the case of $\mathbf{1}$. By the HMBC correlations of the protons $\mathrm{H}-3\left(\delta_{\mathrm{H}} 5.22\right), \mathrm{H}-5\left(\delta_{\mathrm{H}} 5.83\right)$, and H-7 $\left(\delta_{\mathrm{H}} 4.79\right)$, with the corresponding carbonyl signals at $\delta_{\mathrm{C}} 173.4,169.1$, and 170.2, the two acetoxy groups and the 
propinoyloxy group were attributed to $\mathrm{C}-5, \mathrm{C}-7$, and $\mathrm{C}-3$, respectively. There were no long-range correlations observed for $\mathrm{H}-14\left(\delta_{\mathrm{H}} 4.05\right)$ to the carbonyl carbons of the acyloxy groups, which indicated that the substituent at $\mathrm{C}-14$ was a hydroxy group based on the chemical shift for $\mathrm{C}-14$. The remaining two acetoxy groups and one isobutyryl group were assigned to $\mathrm{C}-10, \mathrm{C}-15$, and $\mathrm{C}-2$, respectively, which was supported by the NOESY correlation of the $\mathrm{H}-14\left(\delta_{\mathrm{H}} 4.05\right)$ and $\mathrm{H}-1 \beta\left(\delta_{\mathrm{H}} 2.13\right)$ to the methyl protons $\left(\delta_{\mathrm{H}} 1.91\right)$ of the $\mathrm{C}-15$ acetoxy group and the $\mathrm{H}_{3}-19\left(\delta_{\mathrm{H}} 1.48\right)$ to the methyl protons $\left(\delta_{\mathrm{H}} 2.04\right)$ of the $\mathrm{C}-10$ acetoxy group. The similar myrsinol-type diterpene skeleton of 2 compared to those of compound 1 implied the same trans-fusion of the three rings $(5 / 7 / 6)[7,13]$. The NOESY correlations of $\mathrm{H}-3 / \mathrm{H}-4, \mathrm{H}-5 / \mathrm{H}-12, \mathrm{H}-14 / \mathrm{H}-12, \mathrm{H}-7 / \mathrm{H}_{2}-17$, and $\mathrm{H}-12 / \mathrm{H}_{3}-20$ suggested that the $\mathrm{C}-3$ propinoyloxy group and the $\mathrm{C}-7$ acetoxy group were $\beta$-oriented, while the $\mathrm{C}-5$ acetoxy group and $\mathrm{C}$-14 hydroxy group were $\alpha$-oriented. Thus, compound 2 was elucidated as $2 \alpha-O$-isobutyryl-3 $\beta-O$ propionyl-5 $\alpha, 7 \beta, 10,15 \beta$-tetra- $O$-acetyl-10,18-dihydromyrsinol.

Compound 3 was obtained as a white powder. The molecular formula of $\mathbf{3}$ was determined to be $\mathrm{C}_{44} \mathrm{H}_{50} \mathrm{O}_{15}$ by HR-ESI-MS ( $m / z 841.3040[\mathrm{M}+\mathrm{Na}]^{+}$, calcd. for $\mathrm{C}_{44} \mathrm{H}_{50} \mathrm{O}_{15} \mathrm{Na}$ 841.3047), which was compatible with the NMR data. On comparing the chemical shifts for the skeletal carbons in 3 with those for C-1-C-20 in compound $\mathbf{1}$, the almost coincidence implied that compounds $\mathbf{3}$ and $\mathbf{1}$ had the same characteristic 10,18-dihydromyrsinol skeleton [4,5,7]. The only difference between $\mathbf{3}$ and $\mathbf{1}$ was that the one isobutyryloxy group in $\mathbf{1}$ was replaced by a benzoyloxy group in $\mathbf{3}$, which was deduced based on the ${ }^{13} \mathrm{C}$-NMR spectrum and the chemical shifts for the benzoyloxy groups in the reported myrsinol diterpenes [7,13]. Following the same NMR procedures used for 1, the locations of the acyloxy groups in $\mathbf{3}$ were determined by the analysis of the HMBC spectrum, which revealed that the five acetoxy groups were attached at C-3, C-5, C-7, C-10, and C-15, and the two benzoyloxy groups were at C-2 and C-14, respectively. The same relative configuration to be inferred for compound 3 and compound $\mathbf{1}$ was revealed by the careful comparison of the NOESY spectra of $\mathbf{3}$ and $\mathbf{1}$. The structure of compound 3 was therefore characterized as $2 \alpha, 14 \alpha$-di- $O$-benzoyl-3 $\beta, 5 \alpha, 7 \beta, 10,15 \beta$-penta- $O$-acetyl10,18-dihydromyrsinol.

Table 2. ${ }^{13} \mathrm{C}-\mathrm{NMR}$ spectroscopic data for compounds $\mathbf{1}-\mathbf{3}\left(\delta \mathrm{ppm}\right.$ in $\left.\mathrm{CDCl}_{3}\right)$.

\begin{tabular}{|c|c|c|c|c|c|c|c|c|}
\hline Position & 1 & 2 & 3 & \multicolumn{2}{|c|}{ Position } & 1 & 2 & 3 \\
\hline 1 & $47.3 \mathrm{CH}_{2}$ & $46.2 \mathrm{CH}_{2}$ & $46.2 \mathrm{CH}_{2}$ & 2-OR & 1 & $175.3 \mathrm{C}$ & $175.1 \mathrm{C}$ & $129.8 \mathrm{C}$ \\
\hline 2 & $86.3 \mathrm{C}$ & $86.8 \mathrm{C}$ & $87.4 \mathrm{C}$ & & $2 / 6$ & $34.3 \mathrm{CH}$ & $34.6 \mathrm{CH}$ & $129.3 \mathrm{CH}$ \\
\hline 3 & $77.7 \mathrm{CH}$ & $78.6 \mathrm{CH}$ & $78.7 \mathrm{CH}$ & & $3 / 5$ & $18.2 \mathrm{CH}_{3}$ & $18.8 \mathrm{CH}_{3}$ & $128.0 \mathrm{CH}$ \\
\hline 4 & $47.6 \mathrm{CH}$ & $44.9 \mathrm{CH}$ & $47.5 \mathrm{CH}$ & & 4 & $18.8 \mathrm{CH}_{3}$ & $18.9 \mathrm{CH}_{3}$ & $132.5 \mathrm{CH}$ \\
\hline 5 & $68.5 \mathrm{CH}$ & $68.2 \mathrm{CH}$ & $68.5 \mathrm{CH}$ & & 7 & & & 164.6 C \\
\hline 6 & $53.3 \mathrm{C}$ & $53.9 \mathrm{C}$ & $53.4 \mathrm{C}$ & $3-\mathrm{OR}$ & 1 & $170.3 \mathrm{C}$ & $173.4 \mathrm{C}$ & $170.5 \mathrm{C}$ \\
\hline 7 & $62.7 \mathrm{CH}$ & $62.9 \mathrm{CH}$ & $62.8 \mathrm{CH}$ & & 2 & $21.0 \mathrm{CH}_{3}$ & $27.9 \mathrm{CH}_{2}$ & $22.3 \mathrm{CH}_{3}$ \\
\hline 8 & $125.7 \mathrm{CH}$ & $125.4 \mathrm{CH}$ & $125.6 \mathrm{CH}$ & & 3 & & $8.7 \mathrm{CH}_{3}$ & \\
\hline 9 & $129.8 \mathrm{CH}$ & $130.3 \mathrm{CH}$ & $129.0 \mathrm{CH}$ & 5-OAc & 1 & $169.2 \mathrm{C}$ & $169.1 \mathrm{C}$ & $169.3 \mathrm{C}$ \\
\hline 10 & $85.7 \mathrm{C}$ & $85.8 \mathrm{C}$ & 85.7 C & & 2 & $20.9 \mathrm{CH}_{3}$ & $20.8 \mathrm{CH}_{3}$ & $20.8 \mathrm{CH}_{3}$ \\
\hline 11 & $44.5 \mathrm{CH}$ & $44.0 \mathrm{CH}$ & $44.5 \mathrm{CH}$ & 7-OAc & 1 & $170.2 \mathrm{C}$ & $170.2 \mathrm{C}$ & $170.3 \mathrm{C}$ \\
\hline 12 & $36.9 \mathrm{CH}$ & $36.6 \mathrm{CH}$ & $36.9 \mathrm{CH}$ & & 2 & $20.8 \mathrm{CH}_{3}$ & $20.7 \mathrm{CH}_{3}$ & $20.8 \mathrm{CH}_{3}$ \\
\hline 13 & $90.0 \mathrm{C}$ & $90.3 \mathrm{C}$ & $90.0 \mathrm{C}$ & 10-OAc & 1 & $168.4 \mathrm{C}$ & $168.9 \mathrm{C}$ & $168.3 \mathrm{C}$ \\
\hline 14 & $73.4 \mathrm{CH}$ & $71.2 \mathrm{CH}$ & $73.1 \mathrm{CH}$ & & 2 & $22.2 \mathrm{CH}_{3}$ & $22.3 \mathrm{CH}_{3}$ & $22.2 \mathrm{CH}_{3}$ \\
\hline
\end{tabular}


Table 2. Cont.

\begin{tabular}{|c|c|c|c|c|c|c|c|c|}
\hline Position & 1 & 2 & 3 & \multicolumn{2}{|c|}{ Position } & 1 & 2 & 3 \\
\hline 15 & $89.9 \mathrm{C}$ & $89.7 \mathrm{C}$ & $89.8 \mathrm{C}$ & 14-OR & 1 & $129.6 \mathrm{C}$ & & $130.8 \mathrm{C}$ \\
\hline 16 & $18.8 \mathrm{CH}_{3}$ & $18.4 \mathrm{CH}_{3}$ & $18.8 \mathrm{CH}_{3}$ & & $2 / 6$ & $129.9 \mathrm{CH}$ & & $129.6 \mathrm{CH}$ \\
\hline 17 & $69.8 \mathrm{CH}_{2}$ & $69.6 \mathrm{CH}_{2}$ & $69.8 \mathrm{CH}_{2}$ & & $3 / 5$ & $128.3 \mathrm{CH}$ & & $128.1 \mathrm{CH}$ \\
\hline 18 & $25.1 \mathrm{CH}_{3}$ & $24.9 \mathrm{CH}_{3}$ & $25.1 \mathrm{CH}_{3}$ & & 4 & $133.2 \mathrm{CH}$ & & $132.7 \mathrm{CH}$ \\
\hline 19 & $21.2 \mathrm{CH}_{3}$ & $21.0 \mathrm{CH}_{3}$ & $21.0 \mathrm{CH}_{3}$ & & 7 & $165.6 \mathrm{C}$ & & $165.7 \mathrm{C}$ \\
\hline 20 & $24.1 \mathrm{CH}_{3}$ & $24.9 \mathrm{CH}_{3}$ & $24.1 \mathrm{CH}_{3}$ & $15-\mathrm{OAc}$ & 1 & $170.6 \mathrm{C}$ & $170.3 \mathrm{C}$ & $170.4 \mathrm{C}$ \\
\hline & & & & & 2 & $22.4 \mathrm{CH}_{3}$ & $22.3 \mathrm{CH}_{3}$ & $21.1 \mathrm{CH}_{3}$ \\
\hline
\end{tabular}

In order to explore the potential biological activities of these new diterpenes isolated from the roots of E. prolifera, the neuroprotective effects against $\mathrm{MPP}^{+}$-induced neuronal cell death in human dopaminergic neuroblastoma SH-SY5Y cells were evaluated as described previously [11,15]. Bakkenolide $\mathrm{H}$ was used as a positive control [16]. Compounds $\mathbf{1}$ and $\mathbf{2}$ exhibited neuroprotective activities against $\mathrm{MPP}^{+}$-induced neuronal cell death in SH-SY5Y cells. The neuroprotective effects of the two compounds were shown in Figure 3. MTT assay indicated that compounds 1 and $2(3-30 \mu \mathrm{M})$ neither affected the cell viability nor showed significant cytotoxicity with the absence of $\mathrm{MPP}^{+}$(data not shown). Compound $\mathbf{3}$ was not investigated for the neuroprotective effects because of inadequate amount.

Figure 3. Neuroprotective effects of compounds 1 and 2. The SH-SY5Y cells were exposed to $\mathrm{MPP}^{+}$and the cell viability was assessed by MTT assay. The cells were treated with $0.8 \mathrm{mM} \mathrm{MPP}^{+}$in the absence or presence of compounds $\mathbf{1}$ and 2. Data are expressed as the percentage of values in untreated control cultures. Each value indicates a mean $\pm \operatorname{SEM}(\mathrm{n}=3) .{ }^{*} p<0.05$, compared with control group. ${ }^{*} p<0.05$, compared with the $\mathrm{MPP}^{+}$-treated group. Indicated positive control, bakkenolide $\mathrm{H}, 15 \mu \mathrm{M}$.

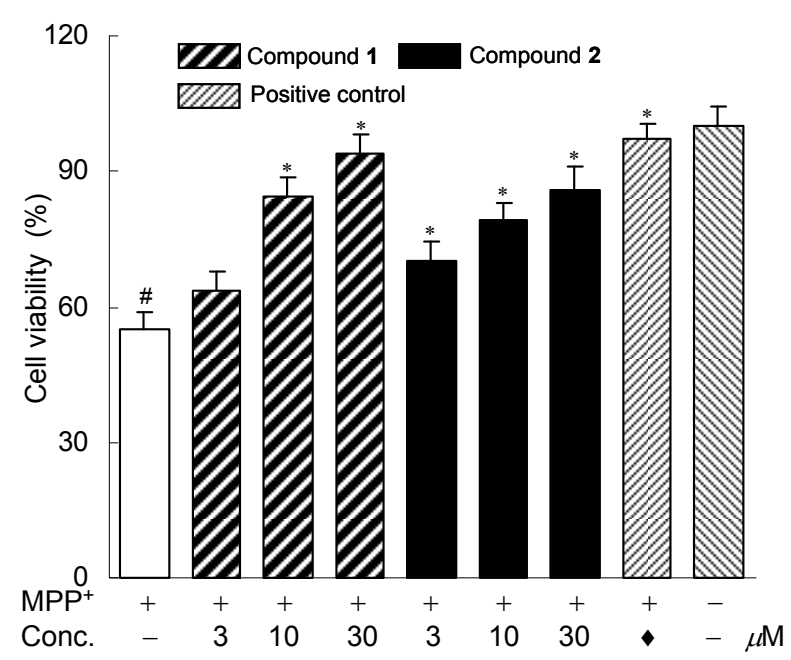

\section{Experimental}

\subsection{General Experimental Procedures}

The IR spectra were taken on a on a Bruker Tensor 27 FT-IR spectrometer with KBr discs. Optical rotations were measured in $\mathrm{CH}_{2} \mathrm{Cl}_{2}$ using an Autopol IV automatic polarimeter. The ESI-MS spectra 
were obtained on a LCQ-Advantage mass spectrometer made by Finnigan Company of America. HR-ESI-MS spectra were obtained using an Ionspec 7.0 T FTICR MS. 1D and 2D NMR spectra were recorded on a Bruker AV 400 instrument (400 MHz for ${ }^{1} \mathrm{H}$ and $100 \mathrm{MHz}$ for ${ }^{13} \mathrm{C}$ ) with TMS as an internal standard. HPLC separations were performed on a CXTH system (Beijing Chuangxintongheng instruments Co. Ltd., China), equipped with a UV3000 detector at $210 \mathrm{~nm}$, and a YMC-pack ODS-AM $(250 \times 20 \mathrm{~mm})$ column. Silica gel (200-300 mesh, Qingdao Marine Chemical Group Co. Ltd., China) was used for column chromatography. Chemical reagents for isolation were of analytical grade and purchased from Tianjin Yuanli Co. Ltd., China. Biological reagents were from Sigma Company. Human dopaminergic SH-SY5Y cells were obtained from Shanghai Institutes for Biological Sciences, Chinese Academy of Sciences (China). Biological reagents were from Sigma Company.

\subsection{Plant Material}

The roots of Euphorbia prolifera Buch-Ham were collected from Kunming, Yunnan Province, China, in July 2010. The botanical identification was made by Dr. Yuanqiang Guo (College of Pharmacy, Nankai University, China), and a voucher specimen (No. 20100705) was deposited at the laboratory of the Research Department of Natural Medicine, College of Pharmacy, Nankai University, China.

\subsection{Extraction and Isolation}

The air-dried roots of $E$. prolifera $(3.8 \mathrm{~kg})$ were powdered and extracted with $\mathrm{MeOH}(3 \times 20 \mathrm{~L})$ under reflux. The solvent was evaporated to obtain a crude extract $(900 \mathrm{~g})$. The extract was suspended in $\mathrm{H}_{2} \mathrm{O}(0.9 \mathrm{~L})$ and partitioned with EtOAc $(3 \times 0.9 \mathrm{~L})$ to afford the EtOAc soluble part after removing the solvents. The EtOAc soluble part $(150.0 \mathrm{~g})$ was subjected to a silica gel column chromatography using a gradient solvent system from $1-40 \%$ acetone in petroleum ether to give eight fractions $\left(\mathrm{F}_{1}-\mathrm{F}_{8}\right)$ based on TLC analyses. Fraction $\mathrm{F}_{8}$ was fractionated by MPLC over ODS eluting with a step gradient from $60 \%$ to $90 \% \mathrm{MeOH}$ in $\mathrm{H}_{2} \mathrm{O}$ to obtain four subfractions $\left(\mathrm{F}_{8-1}-\mathrm{F}_{8-4}\right)$. Subfraction $\mathrm{F}_{8-3}$ was purified by preparative HPLC (YMC-pack ODS-AM, $20 \times 250 \mathrm{~mm}, 73 \% \mathrm{MeOH}$ in $\mathrm{H}_{2} \mathrm{O}$ ) to afford compound 1 ( $16.5 \mathrm{mg}$ ). The further purification of $\mathrm{F}_{8-4}$ with the same HPLC system using $78 \% \mathrm{MeOH}$ in $\mathrm{H}_{2} \mathrm{O}$, resulted in the isolation of compound 3 (3.2 mg). Fraction $\mathrm{F}_{7}$, using the same MPLC (60-90\% $\mathrm{MeOH}$ in $\mathrm{H}_{2} \mathrm{O}$ ), provided four subfractions $\mathrm{F}_{7-1}-\mathrm{F}_{7-4}$, and the further purification of $\mathrm{F}_{7-2}$ by the above HPLC system $\left(70 \% \mathrm{MeOH}\right.$ in $\left.\mathrm{H}_{2} \mathrm{O}\right)$ afforded compound 2 (11.9 mg).

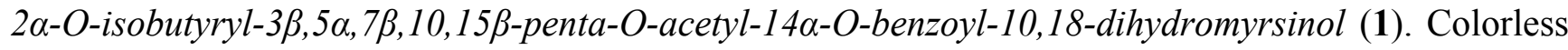
needles $(\mathrm{MeOH}) ;$ m.p. $105-107^{\circ} \mathrm{C}$; $[\alpha]_{\mathrm{D}}^{25}-34.5\left(c=0.17, \mathrm{CH}_{2} \mathrm{Cl}_{2}\right)$; IR $(\mathrm{KBr}) v_{\max } \mathrm{cm}^{-1}$ : 2982, 1739 , 1602, 1452, 1372, 1246; ESI-MS: $m / z 807[\mathrm{M}+\mathrm{Na}]^{+}$; HR-ESI-MS $m / z 807.3195[\mathrm{M}+\mathrm{Na}]^{+}$, calcd. for $\mathrm{C}_{41} \mathrm{H}_{52} \mathrm{O}_{15} \mathrm{Na}$ 807.3204; ${ }^{1} \mathrm{H}-\mathrm{NMR}\left(400 \mathrm{MHz}, \mathrm{CDCl}_{3}\right.$ ) data see Table $1,{ }^{13} \mathrm{C}-\mathrm{NMR}\left(100 \mathrm{MHz}, \mathrm{CDCl}_{3}\right)$ data see Table 2.

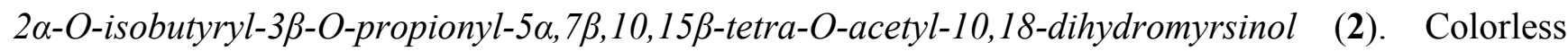
needles $(\mathrm{MeOH})$; m.p. $91-93{ }^{\circ} \mathrm{C}$; $[\alpha]_{\mathrm{D}}^{25}-56.0\left(c=0.62, \mathrm{CH}_{2} \mathrm{Cl}_{2}\right)$; IR $(\mathrm{KBr}) v_{\max } \mathrm{cm}^{-1}: 3524,2982$, 1735, 1462, 1371, 1244; ESI-MS: $m / z 717[\mathrm{M}+\mathrm{Na}]^{+}$; HR-ESI-MS $m / z 717.3101[\mathrm{M}+\mathrm{Na}]^{+}$, calcd. for 
$\mathrm{C}_{35} \mathrm{H}_{50} \mathrm{O}_{14} \mathrm{Na} 717.3098 ;{ }^{1} \mathrm{H}-\mathrm{NMR}\left(400 \mathrm{MHz}, \mathrm{CDCl}_{3}\right.$ ) data see Table $1,{ }^{13} \mathrm{C}-\mathrm{NMR}\left(100 \mathrm{MHz}, \mathrm{CDCl}_{3}\right)$ data see Table 2.

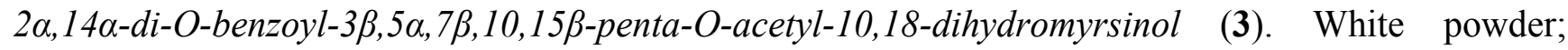
$[\alpha]_{\mathrm{D}}^{25}-73.2\left(c=0.57, \mathrm{CH}_{2} \mathrm{Cl}_{2}\right)$; IR (KBr) $v_{\max } \mathrm{cm}^{-1}: 2955,1742,1452,1373,1246$; ESI-MS: $m / z 841$ $[\mathrm{M}+\mathrm{Na}]^{+}$; HR-ESI-MS $m / z$ 841.3040 $[\mathrm{M}+\mathrm{Na}]^{+}$, calcd. for $\mathrm{C}_{44} \mathrm{H}_{50} \mathrm{O}_{15} \mathrm{Na}$ 841.3047; ${ }^{1} \mathrm{H}-\mathrm{NMR}$ $\left(400 \mathrm{MHz}, \mathrm{CDCl}_{3}\right)$ data see Table $1,{ }^{13} \mathrm{C}$-NMR $\left(100 \mathrm{MHz}, \mathrm{CDCl}_{3}\right)$ data see Table 2.

\subsection{Bioassay for Neuroprotective Activity}

Human dopaminergic neuroblastoma SH-SY5Y cells were cultured at $37{ }^{\circ} \mathrm{C}$ in DMEM supplemented with $10 \%(\mathrm{v} / \mathrm{v})$ inactivated fetal bovine serum and $100 \mathrm{U} / \mathrm{mL}$ of penicillin/streptomycin in a water-saturated atmosphere of $95 \%$ air and $5 \% \mathrm{CO}_{2}$. The cells were disassociated by incubation with $1 \mathrm{mM}$ of ethylene glycol-bis(2-aminoethyl ether)- $N, N, N^{\prime}, N^{\prime}$-tetraacetic acid (EGTA) in phosphate-buffered saline (PBS) for $15 \mathrm{~min}$ and then seeded in 96-well culture plates $\left(1 \times 10^{4}\right.$ cells/well). The cells were incubated at $37{ }^{\circ} \mathrm{C}$ in a $5 \% \mathrm{CO}_{2}$ humidified air incubator for $24 \mathrm{~h}$. The cells were pre-treated for $2 \mathrm{~h}$ with various concentrations $(3,10$ and $30 \mu \mathrm{M})$ of the compounds before incubation in a medium containing 1-methyl-4-phenyl-1,2,3,6-tetrahydropyridine ( $\left.\mathrm{MPP}^{+}\right)$. MTT dissolved in phosphate-buffered saline was added at the end of incubation to a final concentration of $0.5 \mathrm{mg} / \mathrm{mL}$. After incubation for $4 \mathrm{~h}$ at $37{ }^{\circ} \mathrm{C}$ and $5 \% \mathrm{CO}_{2}$, the supernatant was removed and the formed formazan crystals in the viable cells were measured at $490 \mathrm{~nm}$ by using a microplate reader (Thermo Fisher Scientific Inc., USA). Experiments were carried out in triplicate. A statistical analysis was performed by a one-way analysis of variance (ANOVA) followed by post hoc multiple comparisons using the Student-Newman-Keuls method. Data are expressed as the mean $\pm \mathrm{SD}$ of three assays.

\section{Conclusions}

In summary, three new myrsinol diterpenes were successfully isolated from the roots of E. prolifera. Their structures were elucidated on the basis of extensive spectroscopic data analyses. Biological evaluation disclosed that two of them exhibited strong neuroprotective effects against $\mathrm{MPP}^{+}$-induced neuronal cell death in human dopaminergic neuroblastoma SH-SY5Y cells. The results of our chemical investigation further revealed the chemical constituents of E. prolifera. While, the current biological data suggest that myrsinol diterpenes with strong neuroprotective activities may probably be useful for the treatment of nervous system diseases, such as Parkinson's disease [12]. Further biological studies on these compounds are still underway by our group.

\section{Supplementary Materials}

Supplementary data (1D and 2D NMR spectra and HR-ESIMS spectra) associated with this article can be accessed at: http://www.mdpi.com/1420-3049/17/8/9520/s1.

\section{Acknowledgments}

The project was supported by the Natural Science Foundation of China (No. 81102331). 


\section{References}

1. Editorial Committee of Flora of China, Chinese Academy of Sciences. Flora of China; Science Press: Beijing, China, 1997; Volume 44, pp. 118-121.

2. Wu, D.G.; Sorg, B.; Hecker, E. Oligo- and macrocyclic diterpenes in Thymelaeaceae and Euphorbiaceae occurring and utilized in Yunnan (Southwest China). 6. Tigliane type diterpene esters from latex of Euphorbia prolifera. Phytother. Res. 1994, 8, 95-99.

3. Wu, D.; Sorg, B.; Hecker, E. New myrsinol-related polyfunctional pentacyclic diterpene esters from roots of Euphorbia prolifera. J. Nat. Prod. 1995, 58, 408-413.

4. Zhang, W.J.; Chen, D.F.; Hou, A.J. New myrsinol diterpenes from Euphorbia prolifera. Chin. J. Chem. 2004, 22, 103-108.

5. Li, J.; Xu, L.; Wang, F.P. New cytotoxic myrsinane-type diterpenes from Euphorbia prolifera. Helv. Chim. Acta 2010, 93, 746-752.

6. Xu, J.; Guo, Y.; Xie, C.; Li, Y.; Gao, J.; Zhang, T.; Hou, W.; Fang, L.; Gui, L. Bioactive myrsinol diterpenoids from the roots of Euphorbia prolifera. J. Nat. Prod. 2011, 74, 2224-2230.

7. Xu, J.; Jin, D.Q.; Guo, Y.; Xie, C.; Ma, Y.; Yamakuni, T.; Ohizumi, Y. New myrsinol diterpenes from Euphorbia prolifera and their inhibitory activities on LPS-induced NO production. Bioorg. Med. Chem. Lett. 2012, 22, 3612-3618.

8. Rizk, A.-F.M. The chemical constituents and economic plants of the Euphorbiaceae. Bot. J. Linnean Soc. 1987, 94, 293-326.

9. Zhang, W.J.; Chen, D.F.; Hou, A.J. Two novel myrinsol diterpenes from Euphorbia prolifera. Chin. Chem. Lett. 2002, 13, 744-747.

10. Xu, J.; Zhang, P.; Ma, Z.; Guo, Y.; Zhao, X.; Wei, K. Two carabrane-type sesquiterpenes from Vladimiria souliei. Phytochem. Lett. 2009, 2, 204-206.

11. Guo, P.; Li, Y.; Xu, J.; Liu, C.; Ma, Y.; Guo, Y. Bioactive neo-clerodane diterpenoids from the whole plants of Ajuga ciliata Bunge. J. Nat. Prod. 2011, 74, 1575-1583.

12. Dawson, T.M.; Dawson, V.L. Molecular pathways of neurodegeneration in Parkinson's disease. Science 2003, 302, 819-822.

13. Vasas, A.; Sulyok, E.; Martins, A.; Rédei, D.; Forgo, P.; Kele, Z.; Zupkó, I.; Molnár, J.; Pinke, G.; Hohmann, J. Cyclomyrsinane and premyrsinane diterpenes from Euphorbia falcata modulate resistance of cancer cells to doxorubicin. Tetrahedron 2012, 68, 1280-1285.

14. Shi, Q.W.; Su, X.H.; Kiyota, H. Chemical and pharmacological research of the plants in genus Euphorbia. Chem. Rev. 2008, 108, 4295-4327.

15. Xu, J.; Guo, Y.; Li, Y.; Zhao, P.; Liu, C.; Ma, Y.; Gao, J.; Hou, W.; Zhang, T. Sesquiterpenoids from the resinous exudates of Commiphora myrrha and their neuroprotective effects. Planta Med. 2011, 77, 2023-2028.

16. Xu, J.; Yang, B.; Guo, Y.; Jin, D.Q.; Guo, P.; Liu, C.; Hou, W.; Zhang, T.; Gui, L.; Sun, Z. Neuroprotective bakkenolides from the roots of Valeriana jatamansi. Fitoterapia 2011, 82, 849-853.

Sample Availability: Not available.

(C) 2012 by the authors; licensee MDPI, Basel, Switzerland. This article is an open access article distributed under the terms and conditions of the Creative Commons Attribution license (http://creativecommons.org/licenses/by/3.0/). 